\title{
PERKEMBANGAN CACAT RONGGA PADA PROSES EKSTRUSI
}

\author{
Tri Widodo Besar Riyadi \\ Jurusan Teknik Mesin Universitas Muhammadiyah Surakarta \\ JL.A. Yani Tromol Pos 1 Pabelan Kartasura \\ E-mail: tri_wbr@yahoo.com
}

\begin{abstract}
Cavity defect occurs in an extruded product when the remaining billet reaches a certain thickness. This defect can create serious problem in the quality of products because it produces waste material and requires an extra operation for finishing. The requirement of wasting a certain portion of the product becomes undesirable especially for a relatively short, headed product. Since the occurrence of this defect is troublesome in industrial practice, it is important to study the conditions leading to the cavity formation. By using this prediction, it may be possible to stop the process before the cavity starts to develop. In this work, a new measuring technique to monitor the development of cavity defect in forward extrusion was studied. This technique uses electrical contact principle, which detects the contact between metal pins and the leading face of the billet. When the cavity develops, a void or gap between the punch and the billet interface develops, and breaks the electrical current of the circuit. The experiment of extrusion process was undertaken in parallel with a finite element analysis (FEA) using ABAQUS software. It was shown that at a certain distance the cavity defect was revealed. In this work, the cavity formation was investigated by a variation of die reduction. The influence of coefficient of friction, punch speed, and billet thickness was also observed. This study concentrated on improving the understanding of the behavior of metal flow and the development mechanism of cavity formation with the aim of providing general guidance for the extrusion industry in minimizing the cavity defect formation of the extruded product.
\end{abstract}

Keywords: Cavity defect, Forward extrusion, Measuring technique, Finite Element Analysis

\section{PENDAHULUAN}

Cacat rongga terjadi pada produk ekstrusi ketika benda kerja mencapai sisa ketebalan tertentu pada bagian belakang atau kepalanya. Cacat ini dapat menimbulkan masalah yang serius terutama karena menurunkan kualitas produk, yaitu menghasilkan produk yang tak sempurna sehingga memerlukan ekstra operasi penyelesaian akhir (finishing). Kebutuhan untuk membuang lagi sebagian produk menjadi hal yang tak diinginkan khususnya untuk komponen produk dengan kepala pendek, seperti katup motor. Karena kejadian cacat ini menjadi masalah di industri, maka penelitian terhadap kondisi yang menyebabkan terjadinya cacat rongga ini dirasakan cukup penting. Pemantauan terhadap terjadinya cacat rongga selanjutny akan sangat bermanfaat untuk mempelajari dan memprediksi pembentukan cacat rongga. Dengan prediksi ini, maka dimungkinkan untuk menghentikan proses ekstrusi sebelum cacat rongga terjadi dan 
berkembang. Penelitian ini juga menarik karena dapat meningkatkan pemahaman tentang pola aliran material selama terdeformasi pada saat proses ekstrusi. Lebih dari itu, pengetahuan tentang karakteristik cacat pada produk ekstrusi juga sangat penting untuk keperluan perancangan dies dan pemilihan proses yang efektif. Dari sisi pemasaran, jika produk yang dihasilkan mempunyai kualitas tinggi dengan kemungkinan kandungan cacat yang minimal atau bahkan sama sekali tidak terjadi cacat, dalam hal ini berbentuk rongga, maka produsen (manufacturer) dapat mempertahankan jaminan kualitas produksi guna meraih minat konsumen sehingga bisa tetap bertahan dalam persaingan bebas yang sangat kompetitif.

Tujuan dari penelitian ini adalah untuk mengetahui perkembangan terjadinya cacat rongga (cavity defect) yang biasanya terjadi pada bidang belakang komponen produk ekstrusi. Penelitian dilakukan dengan cara pemodelan fisik, dengan alat sensor arus listrik yang berupa pin kontak, dan dengan Metode Elemen Hingga yang menggunakan software ABAQUS. Pengukuran dengan pin kontak dilakukan untuk mengetahui perkembangan pembentukan cacat rongga (cavity) mulai dari awal terbentuknya rongga sampai proses ekstrusi berhenti. Awal terbentuknya cacat rongga disebut sebagai ketebalan kritis dimana proses harus dihentikan di atas margin aman jika tidak menginginkan terbentuknya produk yang cacat. Variabel pokok yang diamati dalam penelitian ini adalah pengaruh reduksi dies terhadap perkembangan rongga. Dengan simulasi ABAQUS, penelitian diperluas lagi untuk menyelidiki pengaruh kecepatan penekanan, koefisien gesek , dan ketebalan benda mula-mula. Pemodelan fisik ditujukan terutama untuk mengamati pola aliran material selama terekstrusi sehingga terbentuk cacat rongga.

\section{TINJAUAN PUSTAKA}

Cacat rongga (cavity defect) seperti terlihat pada gambar 1 telah menjadi subyek penelitian eksperimen oleh beberapa peneliti sebagaimana dilaporkan oleh Johnson (1995) yang mempelajari pembentukan rongga dengan menggunakan sebuah penekan yang diruncingkan guna mempermudah pola aliran material. Menurut Johnson, terdapat hubungan antara pembentukan rongga dengan gaya penekan. Ditemukan juga bahwa, ketika titik pembentukan rongga terjadi, beban tekanan menurun secara cepat. Tekanan tidak bekerja pada keseluruhan bidang penekan dikarenakan terbentuknya rongga.

Atkinson (1972) juga menyelidiki fenomena cacat rongga pada ekstrusi. Penekan cekung dan cembung digunakan dalam pengamatan ini untuk menguji efek sudut penekan berprofil pada benda kerja pada permulaan pembentukan rongga. Pada hasil eksperimen ini, ditemukan bahwa penekan cekung paling unggul untuk menekan permulaan terjadinya rongga dan pelipatan bagian belakang benda. Atkinson juga menggunakan teknik interupsi penekanan untuk menyelidiki perkembangan cacat rongga pada benda kerja silindris. Ketebalan sisa yang bervariasi serta bentuk-bentuk rongga diperoleh dengan menghentikan gerakan penekan pada posisi yang berbeda. Permulaan pembentukan rongga saat ketebalan benda kerja kritis selanjutnya diprediksi dengan ekstrapolasi.

Pemodelan tiga dimensi dengan simulasi untuk mengetahui bentuk cacat rongga juga pernah dilakukan oleh Li (2001). Hasil bentuk cacat rongga yang dihasilkan dalam penelitian ini masih belum sempurna karena bentuk rongga belum silindris. 


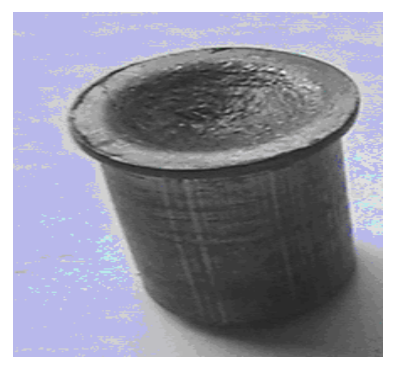

Gambar 1. Cacat rongga produk ekstrusi

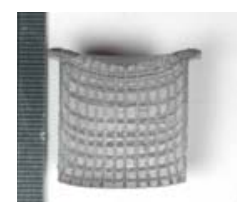

a

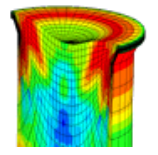

b

\section{Gambar 2. Pola aliran dan bentuk cacat rongga (a) Hasil eksperimen, (b) Hasil simulasi.}

\section{METODOLOGI PENELITIAN}

Penelitian dilakukan dengan dua jenis spesimen yaitu padat utuh silindris dan dibelah simetri vertikal, semua bahan dari timbal dengan diameter $25.4 \mathrm{~mm}$ dan panjang $20.0 \mathrm{~mm}$. Meskipun timbal kurang sensitif terhadap regangan pada suhu kamar, perlakuan panas (annealing) diperlukan untuk memperoleh ukuran butiran yang halus Pada penelitian ini, seluruh spesimen di-annealing dengan meletakkan spesimen di dalam air panas $\left(100^{\circ} \mathrm{C}\right)$ selama kira-kira 20 menit. Empat dies digunakan masing-mesing berdiameter 22, 19, 16, dan $13 \mathrm{~mm}$. Reduksi yang diperoleh dari ke-empat dies ini adalah 0.25, 0.44, 0. 60, dan 0.74. Penekan (punch) yang dibutuhkan pada penelitian ini juga ada dua macam yaitu hollow punch dan padat. Sirkuit peralatan selengkapnya dapat dilihat pada lampiran gambar 8 .

Pemodelan dengan simulasi ABAQUS dilakukan dengan benda silinder dengan ukuran dan property yang sama dengan yang diperoleh dari eksperimen, dimana sifat plastisitas benda diambil dari data uji tekan. Benda uji dianggap axisymmetric deformable, sedangkan dies, kontainer dan punch dimodelkan sebagai analytical rigid surfaces. Pada pengujian pertama, semua permukaan kontak dianggap dipelumasi dengan baik (frictionless). Penelitian selanjutnya dilakukan dengan memberikan penalty pada koefisien gesek semua permukaan yang kontak. Langkah penekanan dilakukan dengan memberikan variasi kecepatan pada punch yang bergerak kearah benda uji. Untuk mengatasi distorsi yang berlebihan maka digunakan adaptive meshing.

\section{HASIL DAN PEMBAHASAN}

Gambar 2 menunjukkan per-bandingan pola aliran material hasil eksperimen dan simulasi yang terjadi pada material dengan reduksi 0.25. Perubahan pola garis menunjukkan adanya deformasi pada benda kerja setelah mengalami penekanan. Deformasi yang terjadi menunjukkan distribusi regangan dari benda kerja saat mengalami tekanan. hasil eksperimen dan simulasi untuk semua reduksi menunjukkan adanya kemiripan bentuk cacat rongga yang terjadi setelah benda di-ekstrusi. 


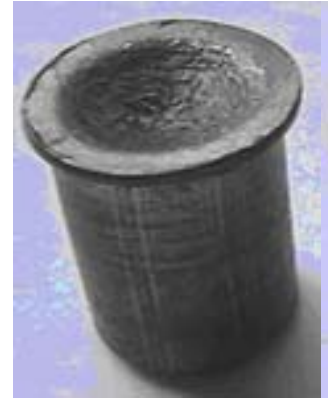

(a)

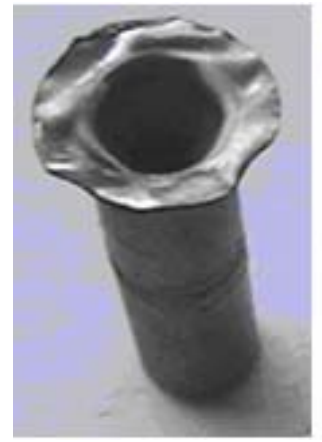

(c)

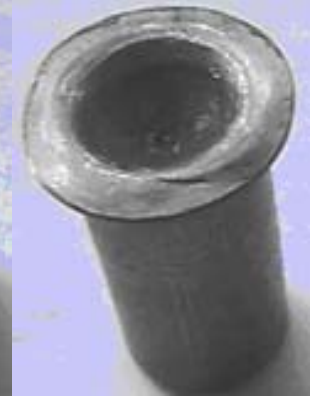

(b)

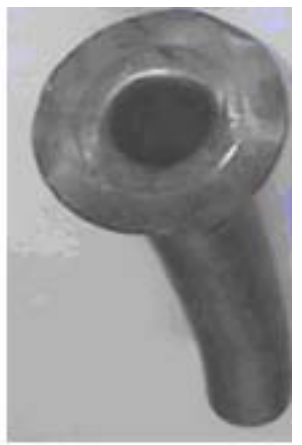

(d)

Gambar 3. Cacat rongga benda uji padat (a). $D=22 \mathrm{~mm},(b) . D=19 \mathrm{~mm}$, (c). $D=16 \mathrm{~mm}$, (d). $D=13 \mathrm{~mm}$ [D = diameter dies ]

Gambar 3 menunjukkan bentuk cacat rongga yang terjadi pada produk benda utuh hasil ekstrusi. Empat dies digunakan untuk mengamati pengaruh reduksi terhadap perkembangan terjadinya cacat rongga. Pengamatan perkembangan rongga dimonitor dengan menggunakan sensor elektronik yang berupa pin bermuatan arus listrik yang dihubungkan dengan sumber arus searah. Perkembangan rongga dapat dideteksi oleh pin ketika arus yang melewati benda kerja dan bersentuhan dengan pin terputus. Sinyal putusnya arus pada penelitian kali ini ditandai dengan matinya lampu indikator.

\section{Perkembangan Cacat Rongga}

Cacat rongga pada produk ekstrusi akan berkembang ke arah radial (makin luas) dan ke arah aksial (makin dalam). Pengamatan terhadap perkembangan cacat rongga pada penelitian ini meliputi perkembangan mulamula atau awal terjadinya rongga, perkembangan kedalaman rongga dan perkembangan jari-jari rongga. Perbandingan akan dilakukan terhadap hasil dari ketiga metode yang digunakan yang meliputi pemodelan fisik, numerik dan penggunaan alat sensor arus listrik. Hasil perkembangan jari-jari rongga yang dimonitor oleh alat dengan sensor arus listrik dapat dilihat pada gambar 4 di bawah ini. Gambar 4 menunjukkan hubungan antara ketebalan kritis terhadap perunbahan reduksi penampang dies, dimana dengan kenaikan reduksi, ketebalan kritis makin turun. 


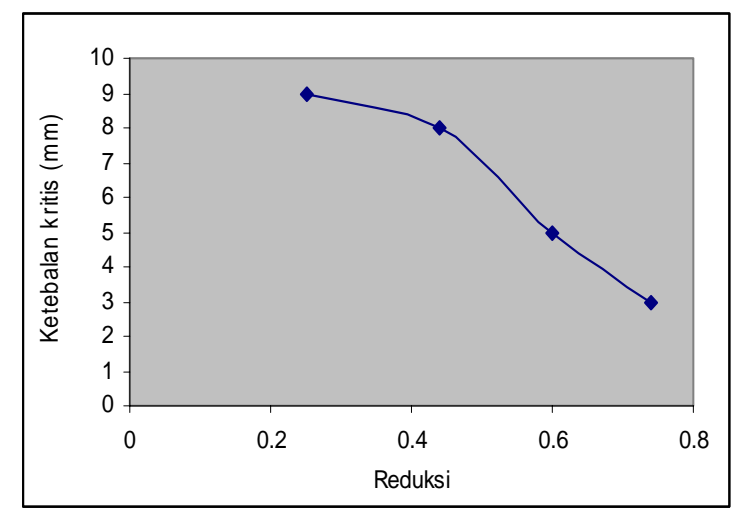

Gambar 4. Hubungan ketebalan kritis benda terhadap reduksi

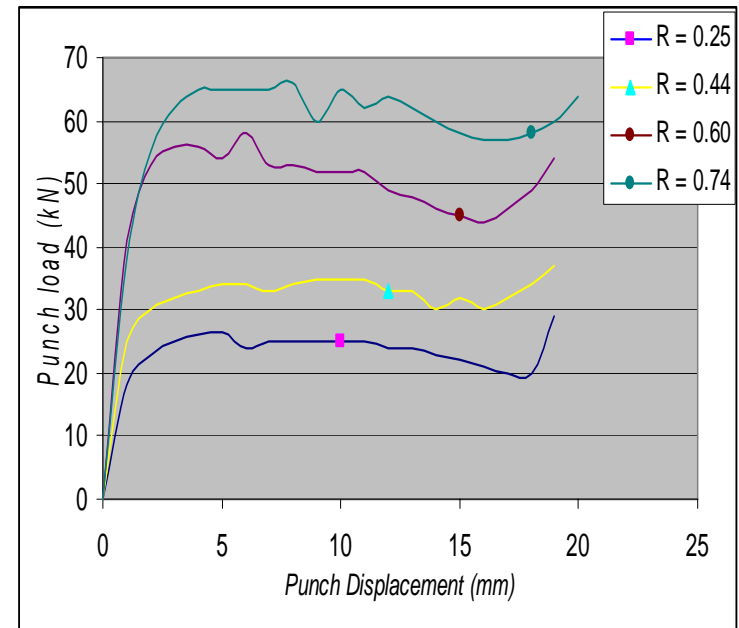

Gambar 5. Hubungan perkembangan terjadinya rongga dengan proses penekanan

Gambar 5 berikut ini menunjukkan perkembangan ukuran rongga mulai dari permulaan dan perkembangan pembentukan rongga, dan hubungannya terhadap beban penekanan (punch load) dan pergerakan penekan (punch displacement) untuk empat reduksi yang bervariasi. Hasil eksperimen ini menunjukkan bahwa semakin besar reduksi maka awal terjadinya cacat rongga semakin menurun. Makin kecil reduksi maka cacat rongga akan makin cepat terjadi. Hal lain yang terlihat adalah bahwa awal terbentuknya rongga terjadi berangsur antara daerah akhir fase tunak (steady-state) dan fase tak tunak (unsteady state). Pada reduksi yang kecil, rongga terjadi lebih awal, masih di daerah steady state.
Sedangkan pada benda uji dengan reduksi besar, rongga terjadi pada daerah unsteady state. Gambar 6 menunjukkan hasil yang diperoleh dari hasil simulasi terhadap bentuk cacat rongga yang terjadi pada benda uji selama mengalami proses ekstrusi. Dari gambar 6 dapat diketahui bahwa perkembangan awal terjadinya cacat rongga sangat dipengaruhi oleh ukuran diameter dies, dimana semakin besar ukuran diameter suatu dies maka cacat rongga yang terbentuk semakin cepat dan semakin lebar, tapi kedalaman rongga pendek, dan semakin kecil ukuran diameter suatu dies maka rongga yang terbentuk semakin lambat dan semakin sempit, tapi kedalaman rongga panjang. 


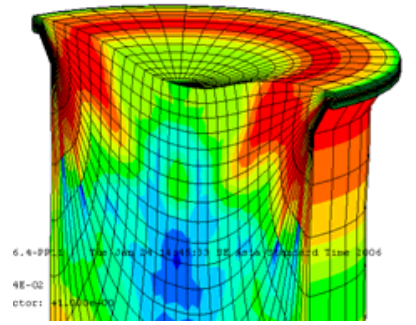

a

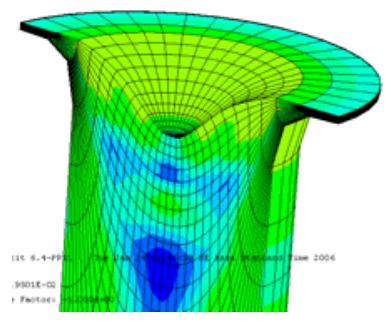

C

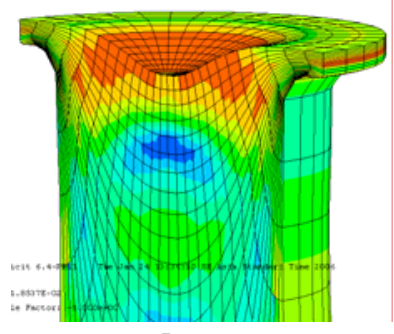

b

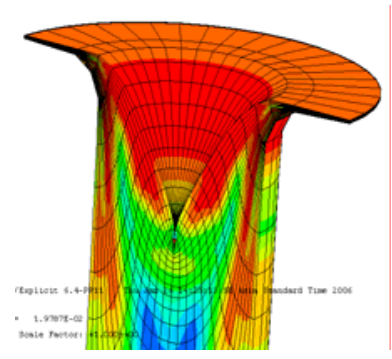

d

Gambar 6. Pengaruh reduksi pada cacat rongga

(a). $R=0.25$, (b). $R=0.44,(c) \cdot R=0.60,(d) \cdot R=0.74$

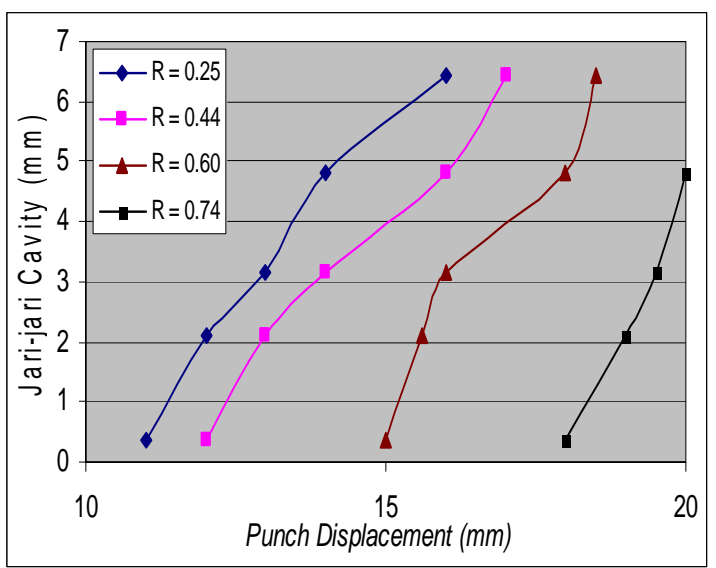

\section{Gambar 7. Grafik perkembangan jari-jari rongga terhadap langkah penekanan}

\section{Perkembangan Jari-Jari Rongga}

Gambar 7 menunjukkan grafik perkembangan jari-jari rongga yang terjadi pada material selama proses ekstrusi pada reduksi yang bervariasi. Grafik ini diperoleh dari penelitian yang menggunakan alat pin sebagai sensor arus listrik. Dari gambar dapat dilihat bahwa perkembangan jari-jari rongga untuk semua reduksi menunjukkan kecenderungan yang hampir sama, yaitu perkembangan jari-jari berjalan hampir lurus atau linier seperti juga ditunjukkan oleh kemiringan kurva.

\section{Pengaruh Koefisien Gesekan}

Penelitian terhadap pengaruh koefisien gesek terhadap bentuk cacat rongga dilakukan dengan menggunakan lima nilai 
perbedaan koefisien gesekan masingmasing $0.0,0.1,0.3,0.5$, dan 0.9 dengan menggunakan dies dengan reduksi 0.25. Hasil penelitian dengan simulasi tentang pengaruh gesekan pada pembentukan cacat rongga menunjukkan bahwa semakin kecil koefisien gesekan maka akan lebih mudah menghasilkan cacat rongga.

\section{Pengaruh Kecepatan Penekanan}

Penelitian terhadap pengaruh kecepatan penekanan terhadap bentuk rongga dilakukan dengan menggunakan empat nilai perbedaan kecepatan penekanan masingmasing sebesar $0.8,1.0,1.2$, dan $1.4 \mathrm{~m} / \mathrm{s}$, dan dilakukan dengan menggunakan dies dengan reduksi 0.44. Hasil penelitian dengan simulasi terhadap pengaruh kecepatan penekanan pada bentuk rongga menunjukkan bahwa pengaruh perbedaan kecepatan penekanan terhadap bentuk rongga cukup signifikan. Bentuk cacat rongga yang terjadi pada benda uji yang ditekan dengan kecepatan lebih rendah cenderung menghasilkan rongga yang lebih besar. Penemuan ini sesuai dengan teori yang menyebutkan bahwa semakin cepat strain rate maka benda akan makin keras.

\section{Pengaruh Ketebalan Benda Kerja}

Penelitian pengaruh ketebalan benda uji pada bentuk rongga yang terjadi setelah mengalami proses ekstrusi dilakukan dengan menggunakan benda uji yang mempunyai ketebalan berbeda masingmasing sebesar 15, 20, 25, dan $30 \mathrm{~mm}$, dan dilakukan dengan menggunakan dies dengan reduksi 0.44. Hasil simulasi menunjukkan bahwa ketebalan benda dapat dikatakan kurang mempunyai pengaruh yang besar pada bentuk cacat rongga.

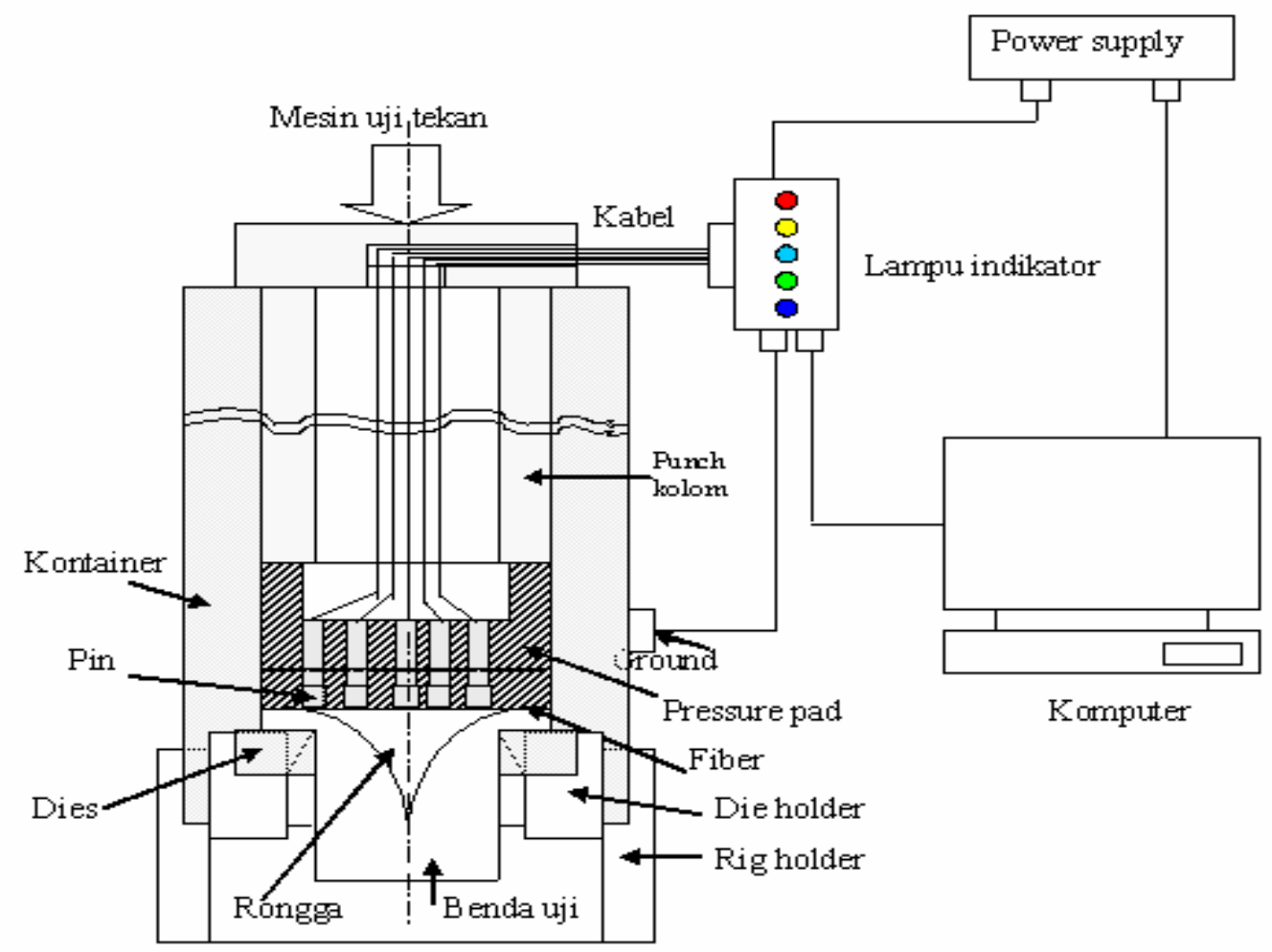

Gambar. 8. Peralatan pengujian dengan pin kontak 


\section{KESIMPULAN}

1. Bentuk cacat rongga hasil eksperimen memberikan hasil yang sama dengan simulasi Perkembangan rongga dapat dideteksi oleh pin ketika arus yang melewati benda kerja dan bersentuhan dengan pin terputus.

2. Pengujian telah berhasil memperoleh karakteristik proses deformasi pada proses ekstrusi, yaitu zona steady-state, zona unsteady-state, dan dead metal zone.

3. Perkembangan cacat rongga pada proses eksptrusi telah diteliti. Hasil eksperimen menunjukkan bahwa perkembangan cacat rongga dipengaruhi oleh reduksi benda uji, koefisien gesekan antar benda uji dan nidang yang kontak dengan benda uji, kecepatan penekanan. Sebaliknya perkembangan cacat rongga kurang terpengaruh oleh perubahan ketebalan benda uji mula-mula.

4. Pemodelan fisik dapat memberikan informasi yang rinci tentang bagaimana cara material mengalir dalam sebuah cetakan/dies.

5. Penelitian ini telah memperlihatkan bagaimana pemodelan fisik dan numerik (ABAQUS) memberikan hasil bentuk cacat rongga yang hampir sama.

6. Simulasi ABAQUS memungkinkan untuk memodelkan konstruksi 3 dimensi yang rumit dengan model yang lebih sederhana dengan mempertahankan kondisi tertentu.

\section{DAFTAR PUSTAKA}

Johnson, W., 1955, Further Experiments in Plane Strain Extrusion, B.I.S.R.A. Reports $\mathrm{MW} / \mathrm{E} / 49 / 55$.

Atkinson, J., 1972, An Investigation of the Coring Defect during Forward Extrusion of Lead, M.Sc Dissertation, Mechanical Engineering Department, UMIST.

G. Li, dkk, 2001, Recent development and applications of three-dimensional finite element modeling in bulk forming processes, J. of Material Processing Technology 113, 40-45.

Tri Widodo Besar Riyadi, 2004, Characterization of Cavity Defect Forward Extrusion, MSc Dissertation, UMIST, UK.

Serope Kalpakjian, dan Steven R. Schmid, 2003, Manufacturing Process for Engineering Material, p.23, Pearson Education, Inc., Prentice Hall. 